\title{
Implementasi Makerspace dalam Layanan Perpustakaan
}

\author{
Nihayati $^{1 *}$; Luki Wijayanti ${ }^{1}$ \\ ${ }^{1}$ Departemen Ilmu Perpustakaan dan Informasi, Fakultas Ilmu Budaya, Universitas Indonesia \\ *Korespondensi: mailniha86@gmail.com
}

\begin{abstract}
Libraries now in the era of disruption where many library tasks could be done by machines or technology. Potensial users and users behaviour have transformend into digital-based and changed very dynamically. Therefore libraries are push to innovate services thatt to meet the need of their stakeholders and technology development, which one of the services is Makerspaces. This study discusses the design and implementation of Makerspace in library services. The benefit of this research is to explain what needs to be considered in developing Makerspace and describing the types of Makerspace library services. Type of research is a qualitative. Data collection by literature and e-observation. Data analysis consists of data reduction, data representation and conclusions collected. The results show that designing service makers need to analysed user needs, attention to law, organizational structure, content collection, infrastructure, interaction and collaboration, competence of librarians and IT expert staff as well as collaboration with related parties. The implementation space implementation in America is very varied, starting from 3D printing, I-Space, virtual space platforms and virtual reality $(V R)$. In the UK, most manufacturing services are still implemented in the form of FabLab. Makerspace library Curtin Australia has also developed 3D printing and virtual reality. Makerspace library in Africa has just reached 3D Printing, in Asia Makerspace has developed into a service in the form of space but has not yet reached the virtual maker space.
\end{abstract}

Keywords: digital library; makerspace; virtual reality; $3 D$ printing

\begin{abstract}
Abstrak
Perpustakaan saat ini masuk di era disrupsi, dimana banyak tugas perpustakaan sudah bisa dikerjakan oleh mesin atau teknologi. Pengguna potensial dan perilaku pengguna perpustakaan pun juga berubah menjadi generasi millennial berbasis digital dan sangat dinamis. Oleh karena itu, perpustakaan dituntut mengembangkan inovasi layanan baru yang mengakomodir kebutuhan pengguna dan perkembangan teknologi. Salah satu perkembangan teknologi yang diadopsi menjadi layanan perpustakaan adalah makerspace. Penelitian ini membahas desain dan implementasi makerspace dalam layanan perpustakaan. Manfaat penelitian ini untuk menjelaskan apa saja yang perlu diperhatikan dalam mengembangkan makerspace dan menggambarkan jenis layanan makerspace perpustakaan. Jenis penelitian merupakan penelitian deskriptif kualitatif dengan metode pengumpulan data melalui studi literatur dan observasi elektronik. Analisis data terdiri dari reduksi data, representasi data dan penarikan kesimpulan. Hasil penelitian ini menunjukkan bahwa dalam mendesain layanan makerspace perlu memperhatikan kebutuhan potensial pengguna, prasyarat hukum, struktur organisasi, konten koleksi,infrastruktur, interaksi dan kolaborasi, kompetensi pustakawan dan staff ahli IT serta kerjasama dengan pihak ketiga. Implementasi makerspace di Amerika sangat bervareasi, mulai dari pencetakan 3D, I-Space, platform virtual space dan virtual reality (VR). Di UK, sebagian besar layanan makerspace masih diimplementasikan dalam bentuk FabLab. Makerspace perpustakaan Curtin Australia juga sudah mengembangkan pencetakan 3D dan virtual reality. Makerspace di beberapa perpustakaan di Afrika berupa pencetakan 3D, sementara di beberapa perpustakaan Indonesia sudah berkembang menjadi layanan dalam bentuk space tetapi belum mencapai virtual makerspace.
\end{abstract}

Kata Kunci : perpustakaan digital; makerspace; realitas virtual; percetakan tiga dimensi

\section{PENDAHULUAN}

Perkembangan teknologi dan informasi berimplikasi pada semua bidang, termasuk perpustakaan. Perpustakaan mulai kehilangan daya tariknya sebagai tempat untuk mencari informasi. Informasi dengan mudah diperoleh di internet melalui gadget atau laptop tanpa terbatas ruang dan waktu. Akses untuk koleksi digital perguruan tinggi saat ini sudah menggunakan remote akses repository (jurnal, thesis, skripsi, ebook dan lainnya), pengguna dapat memanfaatkan layanan tersebut tanpa harus secara fisik mengunjungi perpustakaan. Pengguna potensial perpustakaan saat ini adalah generasi millennial berbasis digital yang notabene kritis, cerdas, terampil, responsif, mendalami informasi secara detail, menyukai sesuatu yang praktis dan menyukai media dalam 
bentuk visual dan mobile. Perilaku pengguna perpustakaan pun mulai bergeser, apabila dahulu perpustakaan dikenal dengan tempat membaca buku yang sepi dan sunyi, saat ini sudah mulai bergeser menjadi tempat belajar kelompok dan berkumpul komunitas untuk mengerjakan tugas bersama atau mendiskusikan suatu masalah.

Pada era disrupsi saat ini sebagian pekerjaan yang dahulunya dikerjakan oleh pustakawan digantikan oleh mesin atau teknologi atau digital. Misalnya dalam layanan sirkulasi, peminjaman dan pengembalian tidak lagi melalui petugas layanan namun dilakukan dengan mesin mandiri (self service). Beberapa layanan perpustakaan di luar negeri sudah mengembangkan vending machine yang dapat diakses 24 jam penuh. Dalam layanan referensi juga sudah dikembangkan sistem virtual yang membimbing pengguna dalam pencarian informasi seperti halnya pustakawan dalam melakukan kegiatan referensi. Perpustakaan harus bisa menyesuaikan dengan perkembangan teknologi dan perilaku pengguna millennial agar tidak tertinggal. Perpustakaan disini dipandang sebagai learning organization sehingga harus terbuka dan responsif terhadap lingkungan, pengetahuan, teknologi dan perkembangan zaman. Perpustakaan harus menggunakan, mengadopsi mengembangkan, menyempurnakan pemikiran, sistem maupun teknik secara berkelanjutan untuk menghasilkan layanan informasi yang lebih efektif dan efisien (Moran, 2007). Salah satu pengembangan inovasi layanan perpustakaan yang mengakomodir kebutuhan pengguna dengan memanfaatkan kemajuan teknologi adalah makerspaces.

Asosiasi teknologi informasi pendidikan tinggi (Educause, 2013) mendefinisikan makerspace sebagai tempat orang berkumpul untuk berbagi sumber daya dan pengetahuan, mengerjakan proyek, jaringan, dan membangun. Makerspace menyediakan alat dan ruang di lingkungan komunitas perpustakaan, pusat komunitas, organisasi swasta, atau kampus. Disediakan juga tenaga ahli, tetapi sering pemula mendapat bantuan dari pengguna lain. Makerspace terkadang disebut sebagai ruang hacker sering dikaitkan dengan bidang seperti teknik, ilmu komputer, dan desain grafis. Makerspace menurut Curry (2017) adalah ruang di perpustakaan untuk para masker untuk berkreasi. Perpustakaan bermitra dengan berbagai organisasi di lingkungan kampus maupun fakultas, baik dari mahasiswa, dosen maupun staf yang mendukung lintas disiplin ilmu, seperti STEM (Science, Technology, Engineering, and Mathematic), history, anthropology, ethnic studies, enterpreneurship (kewirausahaan) dan digital humanities di lingkungan kampus. Makerspace merupakan ruang kerja komunitas berbasis teknologi. Balas (2012) mengaitkan makerspace dengan menciptakan, membangun dan kreatifitas dan mendapatkan pengalaman langsung dalam kegiatan mulai dari makers pekerjaan fisik sampai membangun komputer hingga rekaman audio dan pengeditan video. Sementara Burke (2015) mengungkapkan bahwa makerspaces adalah kombinasi dari komunitas pengguna, kumpulan alat, dan keinginan untuk membuat, bertukar pengetahuan, dan berbagi apa saja. Burke menekankan bahwa mengembangkan layanan makerspace ini seperti orang buta yang menebak bentuk gajah, otoritas ada pada perpustakaan tergantung bagaimana perpustakaan menafsirkan dan mengembangkan bentuk makerspace akan seperti apa.

Penelitian Barry (2015) menunjukkan bahwa perpustakaan adalah tempat yang ideal untuk membangun makerspace. Apabila dahulu perpustakaan memainkan peran penting dalam membantu pengguna mengkonsumsi pengetahuan, perpustakaan kini menyediakan fasilitas bagi pengguna untuk menjadi seorang creator. Perpustakaan dapat menyediakan lingkungan dan teknologi pembelajaran digital yang interaktif untuk pembuatan konten serta teknologi canggih, seperti printer 3D dan pemindai 3D. Makerspace di perpustakaan memungkinkan pengguna untuk berbagi pengetahuan mereka seminari membuat dan belajar secara bersamaan melalui kegiatan seperti pembuatan dan mengedit film, studio rekaman, pemrograman (coding), pencetakan 3D, elektronik,. Banyak makerspace yang menawarkan perpaduan antara akses fleksibel ke dalam peralatan, alat, dan sumber daya untuk proyek individu dan kelompok serta program untuk mendorong pembelajaran, penemuan dan eksplorasi. 
Penelitian Moorefield-Lang (2015) mengungkapkan makerspace di perpustakaan sebagai langkah yang dapat meningkatkan citra pustakawan sebagai inovatif dan mengikuti tren. Pustakawan dituntut untuk merangkul teknologi baru, dan mengelola ruang perpustakaan untuk mendukung inovasi, kreativitas, dan kegiatan DIY; pemotong laser, printer 3D, mesin jahit, fasilitas perbaikan sepeda, mikrokontroler, dan sebagainya. Makerspace pertama perpustakaan umum digagas oleh perpustakaan Perpustakaan Free Fayetteville (FFL) New York bagian utara pada tahun 2012 untuk memberikan akses komunitas ke teknologi, pakar, dan ide inovasi baru untuk mendukung kebutuhan informasi, baik untuk sebuah penemuan maupun konsumsi. Lima tahun kemudian, perpustakaan mulai memasukkan makerspace sebagai sebuah layanan inti, yaitu, berbagi sumber daya dan penciptaan pengetahuan, kemudian diterima baik oleh seluruh profesi. Layanan makerspace memfasilitasi akses ke peralatan dan resources yang sebagian besar pengguna perpustakaan tidak memilikinya. Ketika perpustakaan mulai mengembangkan layanan makerspace, focus utama adalah pengembangan kebijakan.

Di Indonesia penelitian mengenai makerspace dilakukan oleh Mursyid (2016) untuk mengetahui fenomena makerspace sebagai tren baru layanan perpustakaan. Hasil penelitian ini menunjukkan bahwa makerspace merupakan salah satu cara untuk mengembangkan pembelajaran yang inovatif dan kolaboratif di perpustakaan sehingga dapat mendukung penguatan fungsi perpustakaan sebagai pusat kegiatan masyarakat. Untuk dapat mengembangkan layanan ini ada beberapa kompetensi yang harus dimiliki oleh pustakawan, antara lain kemampuan belajar, kemampuan beradaptasi dengan perubahan situasi, kemampuan berkolaborasi, kemampuan mengadvokasi pembelajaran dan kemampuan melayani. Sedangkan kompetensi khusus yang harus dimiliki oleh pustakawan meliputi kemampuan manajerial, kemampuan pengembangan program, kemampuan penggalangan dana, kemampuan penggalangan dana, kemampuan literasi teknologi dan kemampuan fasilitasi pembelajaran.

Penelitian-penelitian diatas membahas mengenai fenomena makerspace sebagai layanan baru di perpustakaan, jenis layanan makerspace dan kompetensi pustakawan yang diperlukan. Jenis layanan makerspace sudah disinggung oleh penelitian diatas, akan tetapi masih implementasi pada satu perpustakaan. Belum ada yang meneliti mengenai apa yang dilakukan oleh perpustakaan sebelum mengembangkan layanan makerspace. Oleh karena itu, penelitian ini membahas mengenai bagaimana mendesain sebuah layanan makerspace dan menunjukkan model-model makerspace yang dikembangkan oleh beberapa perpustakaan di belahan dunia sehingga dapat menjadi gambaran bagi perpustakaan yang hendak mengembangkan layanan ini.

\section{METODE PENELITIAN}

Penelitian ini menggunakan pendekatan deskriptif kualitatif. Penelitian kualitatif merupakan penelitian yang berlandaskan pada filsafat postpositivisme, diperuntukkan untuk meneliti kondisi suatu obyek ilmiah dengan hasil penelitian lebih menekankan makna dari pada generalisasi (Sugiyono, 2016). Metode pengumpulan data menggunakan literatur dan observasi elektronik terhadap beberapa website sesuai lingkup penelitian. Proses analisis data menggunakan teori Miles dan Hiberman dalam (Sugiyono, 2016) meliputi reduksi data, representasi data dan penarikan kesimpulan.

\section{HASIL DAN PEMBAHASAN}

Perpustakaan dituntut untuk memberikan layanan yang memungkinkan akses dan penggunaan yang mudah. Melihat potensi dan peluang perkembangan digital, bentuk perpustakaan harus didesain ulang dengan memasukkan pengguna dalam pengembangan programnya. Dari sudut pandang ini, perpustakaan menyediakan ruang kerja virtual yang tepat dan sangat dibutuhkan, yang merupakan model bisnis masa depan dengan mengembangkan layanan makerspace. (Curry, 2017) 
mengungkapkan bahwa dalam membangun makerspace, struktur organisasi perpustakaan harus didesain ulang dengan berorientasi pada peningkatan dan perluasan misi perpustakaan untuk mendukung penelitian dan lingkaran pendidikan. Interaksi antara pengguna dan pustakawan adalah sebagai professional yang menjalankan kerja kolaborasi dalam makerspace meningkatkan kemampuan perpustakaan dan mengoptimalkan proses dan hasil dari seluruh kegiatan.

Sebelum mengimplementasikan makerspace, perpustakaan harus meninjau bermacammacam makerspace yang sudah ada (seperti FabLabs, hackerspaces dan lain-lain) termasuk mempelajari sejarah, karakteristik, mewujudkan misi perpustakaan sebagai tempat untuk menumbuhkan kreativitas, inovasi, penciptaan dan berbagi pengetahuan. Kemudian menyusun pedoman, saran dan rekomendasi untuk mengimplementasikannya di perpustakaan dengan melihat kebutuhan pengguna. Saran yang dimaksud termasuk mempertimbangkan pembangunan gedung dan manajemen perpustakaan seperti pengembangan koleksi digital, pelayanan dan program sebagai dasar pengembangan makerspace di perpustakaan (Ketchum, 2016). Selain itu perpustakaan juga harus memahami beberapa modul seperti persyaratan hukum, teknis layanan serta peralatan yang memainkan peran penting harus diklarifikasi dengan jelas. Pada saat yang sama, infrastruktur dan layanan yang akan dikembangkan juga harus dievaluasi. Pola organisasi tradisional perpustakaan yang awalnya sebagai penyediaan informasi harus diubah menjadi model organisasi yang meningkatkan misi perpustakaan dengan melibatkan pengguna atau yang lainnya. Konten dan materi digital yang akan disediakan dan ditanam di lingkungan kerja makerspace untuk mengintegrasikan sumber daya dalam proses layanan harus analisis dan operasi (Degkwitz, 2017)

Dalam menerapkan layanan makerspace ini terdapat beberapa tantangan antara lain 1) Technophobia, pustakawan yang lebih muda memang menjadi lebih mengerti teknologi dari sebelumnya. Akan tetapi kebanyakan pustakawan yang lebih tua membentuk populasi yang lebih besar di sebagian besar perpustakaan (bisa jadi disebabkan karena mekanisme perekrutan sesuai jumlah yang pensiun); 2) Hak cipta, ketika makerspace menghasilkan suatu produk atau penemuan baru maka yang perlu diperhatikan adalah hak cipta produk tersebut. Perpustakaan perlu melakukan konsultasi kepada bagian hukum institusi atau yang lain terkait hak cipta atas produk yang dihasilkan; 3) Melatih pengguna, untuk menguasai terminologi dan seluk-beluk makerspace, petugas membutuhkan effort lebih untuk membuat pelatihan terlebih dahulu. Teknologi 3D, virtual reality dan perangkat makerspace lainnya tidak mudah untuk dikuasai, jadi memerlukan waktu lebih lama dari yang diharapkan untuk dikuasai pengguna. Dengan melihat tantangan ini manajer makerspace harus belajar untuk bersabar dengan pengguna dan memberikan waktu yang lebih banyak 4)Security, yaitu keamanan peralatan di makerspace sangat penting mengingat peralatan yang digunakan lumayan mahal, perlu mempertimbangkan pengadaan tenaga keamanan 5) Pendanaan, dana merupakan faktor penting dalam keberlangsungan perpustakaan dengan output layanan nonprofit. Mengingat perpustakaan anggarannya dinilai kecil maka perlu membuat jaringan yang lebih luas untuk supporting dana 6) Maintenance, peralatan listrik dan multimedia seperti bandwidth internet, perangkat keras dan perangkat lunak membutuhkan maintenance. Ini juga menjadi point yang perlu dipertimbangkan oleh perpustakaan dalam mengembangkan makespace 7) Kolaborasi, perpustakaan harus bisa menjalin kolaborasi dengan departemen lain ataupun instansi lain, misalnya bidang IT institusi ataupun laboratorium untuk mendukung pembangunan sebuah makerspace.

Kompetensi pustakawan harus ditingkatkan untuk mengembangkan layanan makerspace. Pustakawan atau staf perpustakaan harus terampil dan terlatih untuk menghadapi tantangan dan tugas yang berkaitan dengan misi baru dalam membentuk makerspace. Pustakawan harus siap untuk peran baru mereka sebagai konektor, mitra kolaborasi dan interaksi ilmiah. Petugas digital (misalnya staf teknologi informasi institusi) harus diajak berkolaborasi untuk bertindak sebagai pekerja pengetahuan. Hubungan antara pustakawan dan pengguna harus dibangun sebagai fondasi 
dasar layanan makerspace. Peran kerja sama pihak ketiga (misalnya konsultan) juga penting dipertimbangkan untuk membantu menyiapkan model perpustakaan baru, karena perpustakaan tidak hanya memberikan sumber daya dan alat mereka sendiri atau kampus, tetapi juga bahan dan layanan dari luar kampus. Perpustakaan bertindak sebagai perantara atau antarmuka dalam skenario layanan baru ini. Dalam upaya meningkatkan keahlian dan kompetensi, pustakawan atau staf perpustakaan perlu diberi pelatihan atau workshop terlebih dahulu. Dari sisi keuangan, perhitungan penganggaran yang tepat juga memainkan peran yang sangat penting dalam kesuksesan penegmbangan layanan makerspace.

Makerspace sudah diadopsi di dalam berbagai layanan perpustakaan di beberapa belahan dunia. Contoh implementasi Makerspace di perpustakaan meliputi, dari 3D printing, platform virtual space dan virtual reality serta FabLab. Apabila perpustakaan hendak mengimplementasikan makerspace dalam pemodelan 3D maka dapat berkontribusi terhadap budaya kreativitas dan inovasi dan banyaknya proyek asli yang sedang dicetak. Kelemahannya printer 3D hanya mencetak pernakpernik pra-desain dari katalog online, tidak banyak berperan dalam mendorong inovasi dan pembelajaran aktif. Pengguna perlu memperoleh literasi yang dibutuhkan oleh teknologi untuk membuat objek yang belum pernah ada sebelumnya kemudian mengubahnya menjadi prototipe, objek pengetahuan, dan ekspresi kreatif. Pada pertengahan tahun 2014 perpustakaan telah meneliti apakah pekerjaan cetak 3D dirancang oleh pengguna saja atau hendak dikembangkan melalui cara lain, seperti katalog online file objek 3D. Selama dua tahun terakhir, lebih dari 80 persen dari semua pekerjaan layanan cetak 3D merupakan kreasi asli (Radniecki, 2017)

Perpustakaan juga dapat mengembangkan layanan makerspace dengan memanfaatkan virtual reality. Virtual reality merupakan teknologi komputer yang dapat membuat interaksi suatu lingkungan yang disimulasikan oleh komputer (Bertol, 1997). Virtual reality ini mendeskripsikan lingkungan tiga dimensi yang dihasilkan oleh komputer dan dapat berinteraksi dengan manusia. Namun kenyataannya virtual reality dan augmented reality (selanjutnya disingkat VAR) sebelumnya tidak dapat diakses oleh perpustakaan karena biayanya yang tinggi dan banyak dikembangkan di bidang swasta profit. Meskipun banyak yang masih tidak memiliki akses ke VAR tersebut, perpustakaan dimungkinkan untuk menyediakan akses ke teknologi ini. Perpustakaan dapat memanfaatkan teknologi VAR ini ke dalam program yang bervariasi. Perangkat paling populer yang saat ini digunakan di perpustakaan menurut Pope (2018) adalah HTC VIVE, Oculus Rift, dan Google Cardboard. The Oculus Rift adalah headset realitas maya sepenuhnya terjangkau pertama yang tersedia di pasaran. Sementara Oculus Rift masih dianggap sebagai salah satu perangkat realitas virtual terbaik dalam bentuk headset, akan tetapi dalam beberapa tahun terakhir terkalahkan oleh daya tarik HTC VIVE.

Berbagai perpustakaan di Amerika mulai dari perpustakaan umum, perpustakaan khusus maupun perpustakaan perguruan tinggi sudah mengembangkan makerspace dalam layanannya. Perpustakaan Universitas Arizona (UA) di Tucson Amerika mengembangkan coworking dan makerspaces baru yang disebut iSpace. iSpace ini merupakan inovasi baru yang melibatkan kreasi belajar dan pengetahuan dalam perpustakaan dan ekosistem kampus. Coworking adalah model kerja yang melibatkan kegiatan secara mandiri di lingkungan kerja bersama. Perpustakaan Makerspaces UA menyediakan ruang kerja yang terpadu antara layanan kewirausahaan (enterpreneurship) dan humaniora digital (digital humanities) di bawah satu atap dan menyediakan kebutuhan penelitian komunitas Universitas Arizona. Layanan makerspace juga sudah dikembangkan di perpustakaan University of Georgia diberi nama The Science Library Makerspace. Layanan ini terdiri dari pencetakan 3D dan virtual reality. Layanan pencetakan 3D dilakukan secara mandiri. Semua pengguna diwajibkan mengikuti pelatihan pencetakan 3D sebelum memanfaatkan layanan ini. Sementara layanan virtual reality hanya digunakan untuk tujuan pendidikan, non-komersial dan harus dibawah pengawasan staf makerspace yang terlatih. Perpustakaan ini juga menyediakan 
fasilitias berupa Arduino, Raspberry, Circuiltly, Vinyl Cuter untuk membuat sebuah produk sehingga makers dapat menjadi pelopor dalam membuat inovasi produk-produk Internet of Things yang bermanfaat. Perpustakaan University of Michigan mengembangkan layanan makerspace berupa virtualspace yang terdiri dari Makerbridge, Michigan Makers dan Digital Badging . Makerbridge merupakan ruang pertemuan komunitas online untuk pustakawan, pendidik komunitas, pemimpin pramuka, guru kelas, penggemar, dan lainnya untuk berkumpul untuk berbagi ide, inspirasi, dan praktik yang efektif dalam menciptakan komunitas dan budaya ruang pembuat. Layanan ini dibuat oleh tim yang dipimpin oleh Sharona Ginsberg (MSI '13), MakerBridge terinspirasi oleh percakapan ini di American Library Association's Maker pada pertemuan Midwinter 2013. Michigan Makers adalah layanan learning dimana tindakan dan pembelajaran layanan untuk mengeksplorasi pengajaran, pembelajaran, dan bukti keterampilan dalam pengaturan non-kelas. Makerspace juga sudah dikembangkan di Perpustakaan Umum yaitu, DC Public Library terdiri dari Fab Lab Pop-Up di NoMa, Memory Lab di Northeast Neighborhood Library, dan Studio Lab Express di Shepherd Park Neighborhood Library. Layanan Fab Lap Pop -Up dibangun dalam wadah pengiriman yang dirancang ulang, melayani pencetakan 3-D dan demo pemotong laser bersama dengan berbagai kelas, lokakarya dan acara. Layanan Memory Lab berupa laboratorium digitalisasi DIY barang-barang pribadi seperti film, foto, slide dan arsip lainnya. Layanan ini juga menyediakan kelas training dan sumber daya lainnya untuk kebutuhan arsip pribadi. Layanan Memory Lab ini mendapatkan penghargaan sebagai fasilitator pelayanan terbaik dalam mendukung kegiatan pengarsipan oleh Institute of Museum and Library Services pada tahun 2017. Sedangkan layanan Studio Lab Express menyediakan akses ke layanan perekaman audio dan layanan pasca produksi untuk video, audio dan musik.

Beberapa perpustakaan di Afrika juga sudah mengembangkan layanan makerspace, salah satunya Layanan Perpustakaan di University of Pretoria (UP) Afrika Selatan membuka Library Makerspace, yaitu sebuah laboratorium kreatif tempat orang-orang untuk membuat ide-ide ini menjadi kenyataan. Makerspace dikaitkan dengan bidang-bidang seperti teknik, ilmu komputer, desain grafis dan seni. Kegiatannya memfasilitasi kelas-kelas tentang elektronik dan pemrograman Arduino, permainan mobile, pengerjaan kulit, bandar, robot finch, desain komputer, dan pengembangan aplikasi dan lain-lain. Kelas-kelas akan diajarkan oleh para ahli kepada tingkat pemula sehingga pemula dapat belajar keterampilan baru.

Sebagian besar layanan makerspace di Eropa, seperti United of Kingdom diimplentasikan dalam bentuk FabLab. FabLab merupakan laboratorium fabrikasi digital yang menyediakan beberapa perangkat, mesin dan alat bantu lain yang dibutuhkan untuk membuat desain, prototype, mockup dan sebagainya. Fablab Perpustakaan Umum Devon adalah satu-satunya laboratorium fabrikasi digital di perpustakaan umum Inggris. FabLab ini berada di Perpustakaan Exeter dan memberikan kegiatan penjangkauan di seluruh Devon. Bentuk layanan berupa pembuatan digital untuk masyarakat umum, sekolah, dan bisnis. FabLab PLUS, Makerspace kedua dari Perpustakaan Umum Devon memiliki serangkaian peralatan komputasi mikro dan sensor Internet of Things, pemotong laser, pemotong vinil, pemanas panas, dan printer 3D. Model FabLab Devon diperluas di Barnstaple dengan rangkaian kreatif iMacs, perangkat lunak Adobe Creative suite, peralatan film dan fotografi. Contoh lain penerapan makerspace adalah kolaborasi dari The Harris Museum, Art Gallery and Library di Preston dan the University of Central Lancashire (selanjutnya disingkat UCLan). Kolaborasi ini muncul untuk mewujudkan misi Harris, menempatkan kreativitas dan membuat space layanan dan ambisi UCLan untuk menjangkau penduduk terpencil di Preston. Layanan ini dibuka pada musim gugur tahun 2016 bersama dengan anggota komunitas dan seniman lokal, menawarkan sebuah layanan untuk membuat dan menciptakan, dari pembuatan kostum hingga coding serta dari menggambar ke drone. Makerspace ini menyediakan alat berteknologi tinggi seperti printer 3D dan scanner digital smapai alat berteknologi rendah seperti kardus dan 
perlengkapan seni. Layanan ini juga menyelenggarakan serangkaian acara diskusi, seminar maupun debat sehingga memperkuat pesan bahwa adalah pusat kegiatan.

Di Australia, Perpustakaan University of Curtin sudah mengembangkan layanan makerspace sebagai kontributor bagi pengembangan budaya para maker untuk mendorong berbagi lintasdisiplin ide, pengalaman dan pengembangan proyek-proyek inovatif yang berkontribusi pada kegiatan pembelajaran dan penelitian civitas Universitas Curtin. Pustakawan membantu mencarikan informasi dan menemukan peralatan diperlukan pengguna untuk memulai suatu kegiatan atau proyek. Pengguna juga diperbolehkan membawa peralatan sendiri. Perpustakaan juga menyediakan layanan pembelajaran mandiri (tidak harus ahli dalam semua bidang kegiatan), dan membantu mencarikan guru atau pengajar atau ahli apabila di perlukan. Layanan ini memiliki perangkat, software, peralatan dan bahan-bahan yang dapat digunakan, diantaranya computer, komponen elektronik, robotic, perangkat VR dan AR, 3D scanner, media kamera, sound, layar, mikrofon dan perangkat pembuatan kerajinan.

Di lingkup Asia Tenggara, Perpustakaan Monash Malaysia sudah memiliki layanan untuk mengakomodasi aktivitas dan ruang belajar siswa yang diberi nama Learning Space. Layanan ini terdiri dari learning common, multipurpose learning space teaching space, quiet zone dan ruang diskusi. Di Pustaka Negeri Sarawak juga sudah mengembangkan layanan berupa kursus atau kelas pelatihan 3D, Arduino, Makey Makey, lego dan robot. Di China, implementasi makerspace mengalami beberapa hambatan seperti yang diungkapkan Ming Li (2018) bahwa makerspace baru dikembangkan pada perpustakaan terkonsentrasi di kota-kota yang lebih kaya, yang khususnya berkaitan dengan adopsi teknologi dan menarik pengguna untuk berpartisipasi dalam kegiatan layanan. Makerspaces telah menarik perhatian para peneliti dan pustakawan di Cina, tetapi dalam prakteknya keduanya masih berada pada tahap primer. Sebagian besar perpustakaan di Cina hanya memenuhi syarat sebagai fasilitas edukasi bagi orang untuk nongkrong dan mencoba menggunakan beberapa teknologi baru. Oleh karena itu kebijakan nasional dan kebutuhan perpustakaan untuk makerspace masih ditinjau dengan melihat pengalaman asing, seperti Inggris dan USA.

Makerspace di Indonesia sebagian besar masih berbentuk fisik atau konvensional, seperti pembuatan kerajinan dan keterampilan dan belum merambah ke layanan virtual makerspace. Makers sebenarnya sudah menuangkan ide-ide kreatif berupa inovasi baru ataupun pengembangan suatu produk yang pernah ada dalam sebuah komunitas besar. Misalnya komunitas makerspace di Indonesia yang dilansir Teknojurnal antara lain Makedonia, Crazy HackerZ, LifePatch, Gerai Cerdas, Bekasi Makerspace, dan Indoestri. Penerapan kegiatan makerspace konvensional sudah dilakukan di beberapa perpustakaan umum daerah, seperti membuat hasta karya, sanggar menulis, membuat puisi dan keterampilan fisik lainnya, belum menjangkau bidang teknologi informasi. Layanan virtual makerspace, baik berupa pencetakan 3D maupun virtual reality belum dikembangkan di perpustakaan. Studio 3D sudah tersedia dilayanan Perpustakaan Umum, Grahatama Yogyakarta, namun hanya sebatas untuk menonton video saja. Konsep dasar virtual reality dikembangkan oleh beberapa perpustakaan perguruan sebagai interface koleksi layanan referensi atau ebook. Di beberapa universitas juga sudah menyediakan ruang untuk pembelajaran yang diberi nama learning commons.

Dari pembahasan di atas implementasi makerspace di United of Kingdom dan Amerika sudah memanfaatkan teknologi VAR dan layanan pencetakan 3D memerlukan biaya yang sangat besar, tentu menjadi hambatan utama dalam penerapan layanan makerspace model ini di perpustakaan Indonesia. Sekali lagi bahwa konsep makerspace adalah inovatif, kolaboratif dan integratif di dalam pengembangannya tergantung pengelolaan perpustakaan sendiri. Hal pertama yang harus dilakukan adalah melakukan kajian kebutuhan pengguna. Dari sinilah perpustakaan dapat menganalisis model makerspace apa yang cocok dikembangkan, apakah sampai pada pemanfaatan teknologi VAR dan sejenisnya atau layanan virtual space atau malah belum mencapai makerspace masih sebatas 
common room atau information room. Setelahnya perpustakaan harus meninjau untuk mempelajari karakteristik, mewujudkan visi misi perpustakaan sebagai space untuk menumbuhkan kreativitas, inovasi, penciptaan dan berbagi pengetahuan. Baru kemudian menyusun organisasi persyaratan hukum, teknis layanan serta peralatan, infrastruktur dan jenis layanan, kolaborasi dan peningkatan kompetensi pustakawan.

\section{SIMPULAN}

Perkembangan teknologi dan perilaku pengguna millennial menuntut perpustakan mengembangkan inovasi layanan, salah satunya adalah makerspaces. Dalam mendesain layanan makerspace hal yang paling penting adalah survei kebutuhan pengguna terlebih dahulu. Peran dan struktur organisasi perpustakaan juga harus diubah disesuaikan dengan misi institusi atau organisasi. Perpustakaan juga menganalisis konten dan materi digital yang akan digunakan dalam layanan makerspace, memahami persyaratan hukum, teknis layanan serta peralatan, infrastruktur dan jenis layanan. Interaksi antara petugas digital dan pustakawan serta kerja kolaborasi dilakukan secara professional. Pustakawan harus meningkatkan kompetensinya di bidang perpustakaan. Contoh implementasi Makerspace di perpustakaan meliputi, dari 3D printing, I-Space, platform virtual space, virtual reality dan augmented reality serta FabLab.

\section{DAFTAR PUSTAKA}

Balas, J. (2012). Do makerspaces add value to libraries?. Computers in Libraries, 32(9), 33. Retrieved from https://remote-lib.ui.ac.id:2155/docview/1152078542?accountid=17242

Barry, T. (2015). Library as place, make the space : makerspace as community development. Australia Library and Information Association 2-5 Februari 2015. Retrieved from http://information-online.alia.org.au/content/library-place-make-space-makerspacescommunity-development

Bertol, D. (1997). Design digital space : an architect's guide to virtual reality. Canada: John Wiley and Sons Inc.

Burke, J. (2015). Makerspace: a practical guide for librarian. Langham: Rowman \& Littlefield.

Curry, R. (2017). Makerspaces: a beneficial new service for academic libraries? Library Review, 66(4/5), 201-212. Retrieved from https://remote-lib.ui.ac.id:2067/10.1108/LR-09-2016-0081

Degkwitz, A. (2017). The interactive library as a virtual working space. LIBER Quarterly, 27(1), 127-137.

Educause. (2013). 7 Things You Should Know About Makerspaces. p. 1. Diunduh dari https://library.educause.edu/resources/2013/4/7-things-you-should-know-aboutmakerspaces

Ketchum, D. (2016). Makerspaces in Libraries. Journal of Access Services, 13(3), 210-211. doi:10.1080/15367967.2016.1208017

Ming Li, W. F. (2018). Exploring the development of library makerspaces in China. Information Discovery and Delivery, 46(2), 127-135. doi:2067/10.1108/IDD-08-2017-0061

Moorefield-Lang, H. (2015). Change in the making: Makerspaces and the ever-changing land scape of libraries. TechTrends, 59(3), 107-112. doi:http://dx.doi.org/10.1007/s11528-015-0860-z 
Moran, R. D. (2007). Library and Information Center Management, Seventh Edition. . United of Kingdom: Library Unlimited.

Mursyid, M. (2016). Makerspace: Tren Baru Layanan di Perpustakaan. Jurnal Ilmu Perpustakaan dan Informasi, $\quad$ 1(1), 29-37. $\quad$ Retrieved from http://jurnal.uinsu.ac.id/index.php/jipi/article/view/97

Pope, H. (2018). Incorporating virtual and augmented reality in libraries. Library Technology Reports, 8-11. Retrieved from https://remotelib.ui.ac.id:2155/docview/2099868562?accountid=17242

Radniecki, T. (2017). Supporting 3D modeling in the academic library. Library Hi Tech, 35(2), 240-250. doi:10.1108/LHT-11-2016-0121

Sugiyono. (2016). Metode Penelitian Kuantitati, Kualitatif dan $R \& D$. Bandung: Alfabeta. 